\title{
Article \\ Self-Employment in Times of Crisis: The Case of the Spanish Financial Crisis
}

\author{
Sergio A. Contreras
}

Regional Economics Applications Laboratory, University of Illinois Urbana Champaign, Urbana, IL 61801, USA; scontre2@illinois.edu; Tel.: +1-217-904-0119

Received: 5 June 2019; Accepted: 23 August 2019; Published: 27 August 2019

\begin{abstract}
While some researchers have suggested that the self-employment (SE) sector is a haven during a financial crisis, others believe that $\mathrm{SE}$ is not necessarily the desired outcome, but an indicator that the labor market is tightening for some groups. Few researchers have compared the SE sector before and after the occurrence of a significant financial crisis, especially in developed countries. This paper analyzes the determinants of entry into self-employment during the 2008 Spanish Crisis. Using data from the Encuesta de Presupuesto Familiar (EPF), results show that although the rate of SE did not experience a significant change during this time, the crisis affected people differently based on gender, with females being more affected than males. Results also suggest differences between Comunidades Autonomas in how the self-employment sector behaved during the crisis.
\end{abstract}

Keywords: self-employment; household determinants; financial crisis

JEL Classification: J21; G01; L26

\section{Introduction}

Economists widely acknowledge that during crises, people who are laid off from their wage jobs turn to self-employment (SE) activities. The literature on small business suggests that microenterprise owners and those who are self-employed are more flexible than their larger counterparts in terms of adjusting to changes in economic situations (Berry and Rodriguez 2001; Narjoko and Hill 2007). According to some economists, this adaptability makes microenterprises and SE activities relatively good economic shock absorbers, especially in fluctuating macroeconomic situations (Sandee et al. 2000; Wennekers and Thurik 1999). Moreover, Alba-Ramirez (1994) found that for the case of Spain and the US, the duration of high unemployment periods significantly increases the probability of becoming self-employed.

Despite these positive views of the benefits of SE during times of crisis, not all authors agree that $\mathrm{SE}$ is necessarily a good condition for workers. Indeed, there is a growing body of literature which suggests that some of these entrepreneurs are being forced into SE by weakness in the labor force or by government and private programs that encourage SE as the only way to overcome poverty (Bateman 2000; Hulme 2000). Mandelman and Montes-Rojas (2009) argued that SE is a form of disguised unemployment, since governments attempt to reduce high unemployment rates by encouraging people to become self-employed, but do not provide enough support. Congregado et al., 2012 found that the number of self-employed firms in Spain creates and destroys employment. On the role of the self-employed as creators of additional job opportunities, Hughes (2003) found that the rise of female $\mathrm{SE}$ and microenterprise ownership in Canada increased due to an involuntary situation rather than a pure entrepreneurial process, resulting in lower SE income compared to their previous paid positions. In Spain, Alba-Ramirez (1994) found that for the same level of expertise and skills, self-employed workers earned less than other workers. These studies are examples of Push SE, where the movement 
from paid work or unemployment to the SE sector is not voluntary, as opposed to Pull SE, where workers actively seek participation in this market.

One of the most recent economic crises is the 2008 Spanish Crisis, hereafter referred to as the Crisis, which lasted until 2014. This Crisis, known as Spain's Great Recession, was caused by a large housing bubble that impacted all areas of the Spanish economy, producing a crash in the financial market system, creating a sharp contraction in the GDP (around 10\%), and doubling the gross public debt (Sevilla Jimenez et al. 2017). The unemployment rate rose from $8.3 \%$ in early 2008 to $26.94 \%$ in the first quarter of 2013 (compared to 6\% in the US and 7.7\% in the UK for the same period), with these figures being record high figures for Spain and the European Union. However, the unemployment Crisis did not affect the Spanish labor force equally. Among the groups most affected by the Spanish Crisis was the population between 18 and 30 years old, with an estimated unemployment rate of $50 \%$ during the period from 2008 to 2013. The Crisis led many young college-educated workers to either migrate or accept mini-jobs, which had a monthly wage of 400 EUR, less than the 644 EUR minimum wage at that time, with no benefits (Arrizabalo et al. 2019; Bartelheimer et al. 2012; Steiner and Wrohlich 2005).

The SE sector in Spain did not have growth proportional to the increase of the unemployment rate. This increase suggests that a different phenomenon occurred during this Crisis compared to developing countries, where people have sought shelter in SE as a coping strategy. Sanchez-Moral et al. (2018) suggested that one of the collateral effects of the Crisis was an interregional mobility of talent inside Spain. Unemployed individuals sought opportunities everywhere in Spain, where larger cities such as Madrid and Barcelona attracted more job seekers than other smaller cities, deepening the impact of the Crisis in these small to medium cities. The Crisis also changed household income and expenditure, especially where the head of the household was self-employed. Bargain and Martinoty (2019) derived the term "mancession" to explain that the Spanish financial Crisis reshaped the household budget structure, suggesting that male self-employees were more affected in terms of budget decision compared to female self-employees, and thus their role in making household purchase decisions changed.

To date, there has been no study of how the Spanish economic crisis affected spatial and temporal dimension groups of the economic spectrum. This paper uses data from Encuesta de Presupuestos Familiares (EPF) to examine how the determinants of SE entry decisions were affected by the 2008 financial Crisis in Spain. This survey was collected by the Instituto Nacional de Estadisticas (INE) in Spain and provides information on consumption, labor supply, and socioeconomic characteristics at the household and individual levels (Bargain and Martinoty 2019, Molina et al. 2016) from 2006 through 2015. The paper models the entry decision as a function of different personal and regional characteristics such as education level, gender, number of dependents, marital status, personal assets, city, and regional characteristics. (Goetz and Rupasingha 2009). The hypotheses that this paper will test are as follows:

H1: The role of these determinants will vary across time and space throughout the financial Crisis.

H2: Among these determinants, the role of education and gender will display a significant effect (with the expectation that females with higher education will move more often from wage paid position to SE activities compared to females with less education).

- H3: The Crisis will have the same impact on all the Comunidad Autonomas (CAs).

Initial results show that most of the determinants categories found in the literature (Personal Characteristics, Income, Education, Personal Assets, and Regional Characteristics) had a negative sign, exceptions being married marital status, age, and the number of dependents (For example, Molina et al. 2016). Although the majority of the determinants were statistically significant outside the period of the Crisis, most of the effect of the Crisis over the SE rate was not significant, suggesting that the Crisis did not strongly affect the SE sector. At the Comunidad Autonoma (CA) level, the Crisis did have an uneven effect over the rate of SE.

The rest of the article is organized into five sections. The next section provides a literature review on the SE sector and its relationship with economic crises. Section Three discusses the empirical model, 
including the data, methodology, and modeling approach. Section Four presents and discusses the empirical results. Finally, Section Five discusses the findings and their implications for policymaking and presents recommendations for further work.

\section{Literature Review}

Although the SE sector is still regarded as a key factor for economic growth in several countries, this sector has not shown steady growth over time. Moreover, until 1970, there was a continuous decline of the share of self-employed to the total labor force in developed countries (Bögenhold and Staber 1991). After 1970, the Organization for Economic Co-operation and Development (OECD) country members regained interest in the notion that SE can overcome low economic cycles. This paper will adopt Blanchflower and Shadforth's (2006) criteria, which defines the self-employed as a person who declares that their primary source of income is SE income, whether this person is a sole proprietor or incorporated as a firm.

Scholars have defined two types of entrepreneur based on the person's reasons for engaging in entrepreneurial activities: Push entrepreneurs and Pull entrepreneurs (Amit and Muller 1995; Dawson and Henley 2012; Hughes 2003; Kirkwood 2009). Push entrepreneurs are defined as entrepreneurs who move from a paid position to entrepreneurship for a non-entrepreneurial reason, whereas Pull entrepreneurs actively seek and embrace more entrepreneurial activities. There has been a belief among policymakers that Push entrepreneurs seek entrepreneurial activities for motivational reasons (i.e., being their own boss); however, that may not be the case when a financial Crisis occurs.

It is debatable whether all types of SE are the desired result per se. Some authors argue that the rise of a push type of SE does not necessarily imply an improved economic situation, but is instead a sign of deficiencies in the labor market (Bögenhold and Staber 1991; Mandelman and Montes-Rojas 2009). According to Prentice (2017), devolvement is the notion, embedded in SE literature, that a higher entrepreneurial activity will contribute to economic growth and thus alleviate poverty situations. To the contrary, Prentice (2017) argued that the rise of SE and microenterprises had worsened labor conditions, especially for women. In line with this criticism, scholars such as Roy (2010) and Bateman (2000) have argued that, rather than improving economic conditions for the entrepreneur, SE and microenterprise merely replicate and perpetuate the neoliberal system. However, others argue that the only way to overcome discrimination and constraint in the labor market is through SE and microenterprises (Bashir et al. 2014). There is also a disagreement regarding whether self-employees earn more than paid employees (Hamilton 2000). Some authors argue that some groups obtain a higher income as self-employees such as optimistic people who voluntarily enter the SE sector compared to people forced to enter the SE sector (De Meza et al. 2019). For instance, Kirkwood (2009) argued that females are more likely to be pushed rather than pulled to SE due to market conditions. Some countries have policies that make pay for females more expensive, causing firms to hire them as self-employees to avoid paying those costs (such as childcare subsidies or maternal protections).

The existing research on SE has focused on specific characteristics of the self-employed, such as gender, age, and education, but less research has focused on how the SE sector changes after the occurrence of a financial Crisis and whether these changes were due to more of a pull condition than a push condition. Also, most of the research that evaluates the effects of a Crisis on SE is based on a Crisis that occurred in developing countries, such as the 1998 Asian Crisis, while fewer studies have addressed how an economic Crisis reshapes the landscape of SE and microenterprise in developed countries.

In the case of the Spanish Crisis, research on the impact of the Crisis has focused on the financial and labor market. In the case of the SE sector, studies have focused on the change of budget decision-making between members of a household (Bargain and Martinoty 2019), employment in general, and the role of capital access through nontraditional financial institutions such as cooperatives (Melián Navarro et al. 2010). However, only a few of them focus on how the initial composition of the SE sector changed due to the financial Crisis. Other studies indicate that the self-employed in Spain have only one client, thus suggesting that the SE sector has evolved from a self-employment activity to a disguised paid 
position. For instance, Romero and Martínez-Román (2012) found that most of the women pursuing SE activity in Spain fall into what they define as false self-employment, where non-employers' firms are filling services that would otherwise be performed by paid employees. The reason behind this firm behavior is to avoid the cost of severance, social security, benefits, and other expenses, suggesting that there is a labor constraint for hiring women.

In terms of modeling, most of the existing literature on labor market decisions assumes that individuals are continuously evaluating moving from paid work to SE or vice versa based upon on current and future market conditions (Mortensen 1986). However, a move from SE to unemployment is often an involuntary decision due to market conditions. According to Millán et al. (2012), the utility differential between SE and other final states is assumed to depend on a set of individual characteristics and economic variables at both the micro and macro levels, such as experience (Evans and Jovanovic 1989; Evans 1987; Holtz-Eakin et al. 1994a, 1994b), gender (Blanchflower and Oswald 1998; Estrin and Mickiewicz 2011; Rupasingha and Contreras 2014; Simoes et al. 2016), immigration status (Fairchild 2009; Fairlie 2004), head of the household (Bargain and Martinoty 2019), number of dependent children (Holtz-Eakin et al. 1994a; Millán et al. 2012), age (Block and Sandner 2009; Holtz-Eakin et al. 1994b; Millán et al. 2012), and access to financial resources (Evans and Jovanovic 1989; Evans 1987; Holtz-Eakin et al. 1994b).

\section{Methodology}

\subsection{Empirical Model}

This paper's theoretical framework is based on the literature focusing on firm entry, growth, and exit (Parker 1996; Hamilton 2000; Goetz and Rupasingha 2009). Most of the research done on the SE sector assumes that individuals in a particular region have only two choices in the labor market: to work as a self-employee or as a paid employee. The literature casts this decision as being based on a person's desire to maximize his/her utility function (higher expected future income).

Following Parker (1996); Hamilton (2000); and Goetz and Rupasingha (2009), the utility function for an individual as a self-employee can be written as:

$$
\pi_{i t}=P(\eta) q(l: \tau)-v M
$$

where $\pi_{i t}$ is the profit or net income from a person who pursues a SE activity, $P$ represents the price of the SE activity based on a certain risk level; $q(l: \tau)$ is the labor output based on his/her entrepreneurial activity; and $v M$ is the cost of producing the entrepreneurial activity.

Let $\omega_{i t}$ be the wage of a paid employee $i$ in time $t$. Someone's decision to become self-employed takes place when the wage as a self-employee is higher than the equivalent wage as a paid employee. This relationship can be written as follows:

$$
\pi_{i t}-\omega_{i t}>0
$$

However, there are instances when one becomes self-employed but does not maximize one's utility function. For instance, Lazear (2004), states that entrepreneurs are being paid for the least of their set of skills compared to paid employees, who are paid by their best skill. Other scholars such as Bateman (2000) and Millán et al. (2012) argue that, in the event of a financial Crisis, entering SE is not necessarily an option but rather the only way to overcome difficult times. Therefore, a more generalized version of Equation (2) needs to consider that the decision to become self-employed may be a function of additional determinants. Based on Gentry and Hubbard (2000, 2004), Equation (2) becomes:

$$
S E_{i j, \tau+1}=f\left(e_{i \tau}, x_{i \tau}, z_{i \tau}, \gamma_{i}\right)
$$


where $e$ is education, $x$ represents a matrix of personal characteristics, $z$ represents other household characteristics, and $\gamma$ represents regional characteristics. This reduced form can be expressed as a linear combination between the decision to become an entrepreneur and a series of determinants:

$$
S E_{i j, \tau+1}=\alpha+B^{\prime} X_{i j \tau}+\gamma_{i}+\theta_{\tau}+\varepsilon_{i j \tau}
$$

where $\gamma_{i}$ and $\theta_{\tau}$ are regional and time fixed effects, respectively (H1 above). Regional fixed effects capture the innovative milieu that some regions may display to a higher level than others (Gobillon and Magnac 2015). Time fixed effects account for events that affect the entire country in the same way, such as a change in national policy. $X$ is a matrix with all the determinants that affect the $\mathrm{SE}$ decision (H2 above). Among them, gender will be interacted with a dummy $=1$ from 2013-on in order to determine whether the Crisis affected the determinants for self-employed females in the same way as self-employed males (H3 above). Most of the studies on SE use a set of determinants similar to Equation (4). Indeed, most of such determinants capture individual characteristics and economic variables at both the micro and macro levels, previously discussed in the literature review section.

For evaluating the Crisis, the model included a dummy variable that accounts for the period when the Crisis was in place (2008-2013) as an interaction term. This variable interacted with the rest of the coefficients will allow evaluating whether the Crisis changed the factors that affect the decision to enter the SE sector. The model will be estimated using the total population, using the female subgroup and the male subgroup. In the next section, data collection and the variables used for estimating the model will be discussed.

\subsection{Data}

For the individual characteristics, this paper will use the Encuesta de Presupuestos Familiares or EPF (Survey of Family Budget), which examines Spanish household consumption and expenditures. This survey is collected by the Spanish Instituto Nacional de Estadisticas, INE (National Bureau for Statistics) and is representative of the whole Spanish territory. This survey also includes the population weight factor that each household represents. The unit of scale that this dataset uses is household level, with more than 26,000 households surveyed and with the weight factor included for each of them. Although the primary purpose of this survey regards household expenditure, this survey provides information about household employment status and demographics, including characteristics for each household member. Some information was at the individual level; the survey only has detailed information for the household head.

Although the survey has data from 1998 and onward, a 2006 change in methodology made data from previous years incompatible. Therefore, the data for this study was restricted to the years 2006 to 2015. Also, the dataset did not have all the information of Ceuta and Melilla for this period, and thus these CAs were removed. Finally, observations that had nulls or did not answer were removed. Table 1 shows a descriptive summary of the variables used for estimating all models. 
Table 1. Descriptive summary of variables.

\begin{tabular}{|c|c|c|c|c|c|c|c|c|c|c|c|c|}
\hline \multirow{2}{*}{ Variable } & \multicolumn{4}{|c|}{ Pooled $($ Obs $=207,917)$} & \multicolumn{4}{|c|}{ Males $(\mathrm{Obs}=153,403)$} & \multicolumn{4}{|c|}{ Females $(\mathrm{Obs}=54,514)$} \\
\hline & Mean & SD & Min & Max & Mean & SD & Min & Max & Mean & SD & Min & $\operatorname{Max}$ \\
\hline SE Rate & 0.14 & 0.35 & 0 & 1 & 0.15 & 0.36 & 0 & 1 & 0.11 & 0.31 & 0 & 1 \\
\hline Age & 53.32 & 14.94 & 16 & 85 & 53.5 & 14.7 & 16 & 85 & 52.7 & 15.7 & 16 & 85 \\
\hline Age Squared & 3066 & 1656 & 256 & 7225 & 3080 & 1625 & 256 & 7225 & 3025 & 1743 & 256 & 7225 \\
\hline Married & 0.68 & 0.47 & 0 & 1 & 0.81 & 0.39 & 0 & 1 & 0.3 & 0.46 & 0 & 1 \\
\hline Number of Dependent & 1.03 & 1.01 & 0 & 12 & 1.05 & 1.02 & 0 & 12 & 0.96 & 0.97 & 0 & 8 \\
\hline Income (Log) & 7.4 & 0.6 & 1.9 & 0.4 & 7.5 & 0.6 & 1.9 & 10.4 & 7.3 & 0.7 & 3.2 & 10.0 \\
\hline Less than High school & 0.23 & 0.42 & 0 & 1 & 0.23 & 0.42 & 0 & 1 & 0.22 & 0.41 & 0 & 1 \\
\hline High school & 0.32 & 0.47 & 0 & 1 & 0.34 & 0.47 & 0 & 1 & 0.27 & 0.44 & 0 & 1 \\
\hline Some College & 0.17 & 0.38 & 0 & 1 & 0.17 & 0.38 & 0 & 1 & 0.17 & 0.38 & 0 & 1 \\
\hline College or more & 0.28 & 0.45 & 0 & 1 & 0.26 & 0.44 & 0 & 1 & 0.34 & 0.48 & 0 & 1 \\
\hline State Capital & 0.33 & 0.47 & 0 & 1 & 0.31 & 0.46 & 0 & 1 & 0.4 & 0.49 & 0 & 1 \\
\hline Low-value House & 0.12 & 0.33 & 0 & 1 & 0.13 & 0.34 & 0 & 1 & 0.1 & 0.3 & 0 & 1 \\
\hline Medium Value House & 0.79 & 0.41 & 0 & 1 & 0.78 & 0.41 & 0 & 1 & 0.81 & 0.39 & 0 & 1 \\
\hline High-value House & 0.08 & 0.28 & 0 & 1 & 0.08 & 0.27 & 0 & 1 & 0.09 & 0.29 & 0 & 1 \\
\hline Urban City & 0.8 & 0.4 & 0 & 1 & 0.79 & 0.41 & 0 & 1 & 0.85 & 0.36 & 0 & 1 \\
\hline
\end{tabular}

\subsubsection{Dependent Variable}

This paper is interested in the factors that influence the decision of a household head to enter the SE sector. To determine whether a household head is pursing SE activities, one of the questions of the EPF survey regards what activity the head of the household had during the year of the survey. A binary variable capturing whether the household head is self-employed can be defined as follows:

$$
\mathrm{SE}_{i}=\left\{\begin{array}{cc}
1 & \text { If the household head is self-employed } \\
0 & \text { Otherwise }
\end{array}\right.
$$

\subsubsection{Covariates}

As mentioned in the empirical model section, this paper models the decision of a person to enter the labor market as a function of different personal and regional characteristics. Among these characteristics, this paper uses age, personal characteristics (marital status, number of dependents), educational level, personal assets (house value and income level), regional characteristics (state capital, urban settlement), time, and fixed effects variables.

In the case of age, this paper is interested in whether there is a difference in how younger women might be more inclined to become SE compared to males. Other studies such as Cetin et al. (2016) found that younger females tend to start their businesses later in their life, compared to their male counterparts. One of the explanations that researchers provide is that females in the SE sector would have more flexibility in terms of working conditions (Arenius and Kovalainen 2006). However, in times of Crisis, this flexibility would not be due to family preferences; rather, it would be the only way to access the labor market. Furthermore, the age squared is included in the estimation for a more accurate estimation of the effect of age on the self-employment rate (Blanchflower 2004; Fairlie 2004). The expectation that age coefficient will have a nonlinear form and with negative slope for younger females and males, yet negative for older females and males. In the SE literature, there are many examples of low-educated women starting a business using microlending programs such as the Grameen Bank. However, there are fewer studies on how education levels affect women's decisions to enter the SE sector. The expectation is that females with more education will have a higher rate of entry compared to women that have a lower education level.

Household income also plays a role when it comes to whether the household head enters the SE sector. One of the barriers that may face a person to engage SE is the lack of collateral for obtaining financing. Ariza Montes et al. (2013) showed that females engage in SE activities with less initial capital and are more likely to start a business if the household has a higher level of income. Therefore, the expectation is that household income has a stronger positive relationship for females than males. The same explanation can be used for married people, where the expectation is that families may have 
multiple sources of income, meaning that the likelihood of a married person entering the SE sector will be higher. Additionally, the number of dependents was included as a covariate, since research shows that females are more risk-averse if they have families. We thus expect that an increasing number of children will have a negative impact on the decision to enter the SE sector.

In the case of regional characteristics, variables were included to capture whether the city is defined as an urban settlement (Urban City) and whether the city where the household is located is a state capital using and a dummy variable for each of the CAs for fixed effects. The two first variables were used as proxies for social capital and access to services. The underlying assumption is that urban and capital cities would have better access to programs and financial services, compared to their rural counterparts. To capture the time trend, the model included dummy variables for each of the years 2006-2015 as time trends. Finally, a dummy variable was created to test the effect of the Crisis. This variable takes the value one from 2008 to 2013 and zero for the rest of the years. Then variables were created using the covariates interacting with the Crisis variable.

\section{Results}

\subsection{Exploratory Analysis}

Figure 1 shows the evolution of the SE proportion by gender, showing a continuous decline of SE during the Crisis (2008-2013) and some recovery phase afterward. However, the recovery after the Crisis was not the same within gender categories. Although females experienced a continuous increase after the Crisis, these levels are far from the levels that females had before the Crisis, whereas males had a recovery during 2013, but saw it go down again. Nevertheless, neither of these groups recovered their pre-Crisis level.

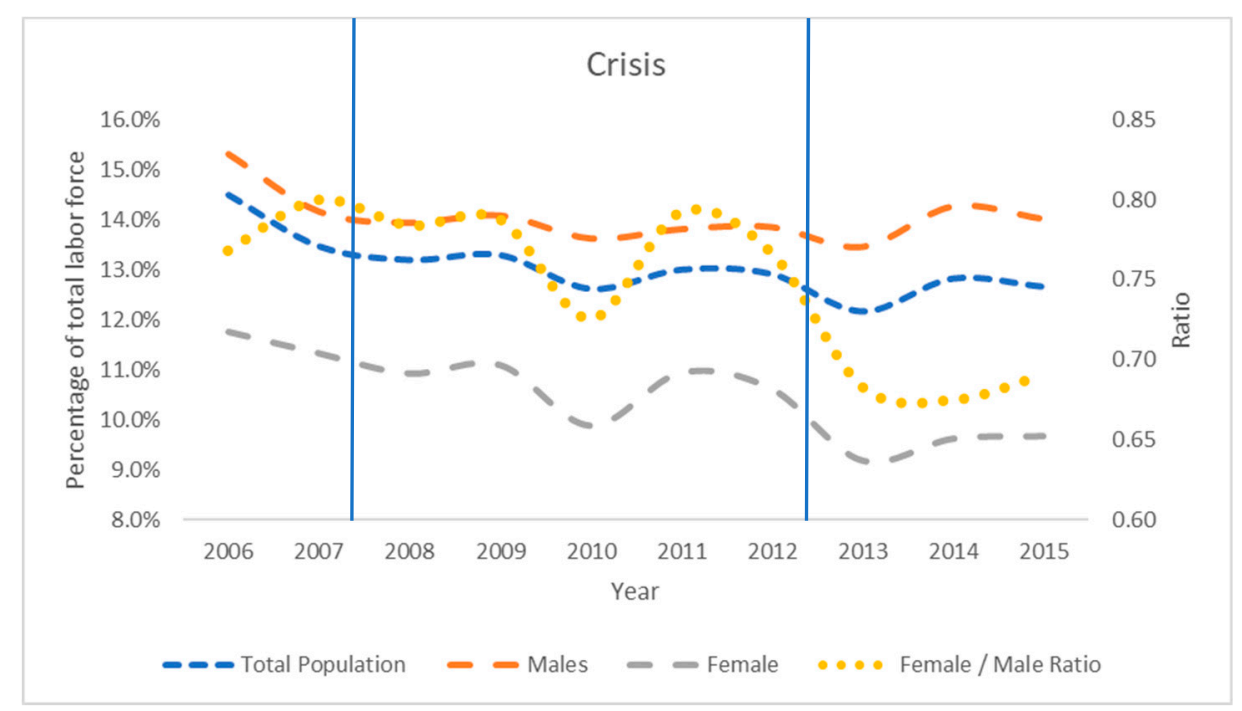

Figure 1. Evolution of the SE proportion by gender and the ratio between female and males.

Figure 1 shows that SE was experiencing a decline in the rate before the Crisis started. This downward trend can be partially explained with the fact that the employment sector in general experienced a $36 \%$ increase in the unemployment rate in the period of 2007-2008. Interestingly, the ratio of female-to-male self-employed was showing an upward trend, suggesting that the self-employment sector was absorbing more females than males. Yet this trend changed during the Crisis with cycles where the ratio was similar to the pre-Crisis period yet after 2011 showed a sharp decline, showing less women were in the self-employment sector, since the male rate was steady during the Crisis period. These results confirm Koellinger et al.'s (2013) findings that females had a lower propensity to start businesses, reinforcing the importance of separating the Crisis's impact on the SE sector by gender. 


\subsection{Regression Analysis}

After the initial exploratory analysis, Equation (4) was estimated using the pooled data and then divided the dataset by gender. Since the dependent variable is a binary variable, the estimation procedure used was logistic regression. The omitted categories were less than high school for education; low value home for house value; the year 2006 for time trend; and Andalucía for the CA dummies. Table 2 shows the transformation of the logistic regression into the marginal effects $(\mathrm{d} y / \mathrm{d} x)$ of the variables to the dependent variables which have a more coefficient straightforward interpretation than the coefficients that the logistic regressions provide. The discussion will be divided first into the results provided by the pooled results and then discuss all the determinants comparing the gender differences.

Table 2. Marginals effects for the Logistic Regression (ML).

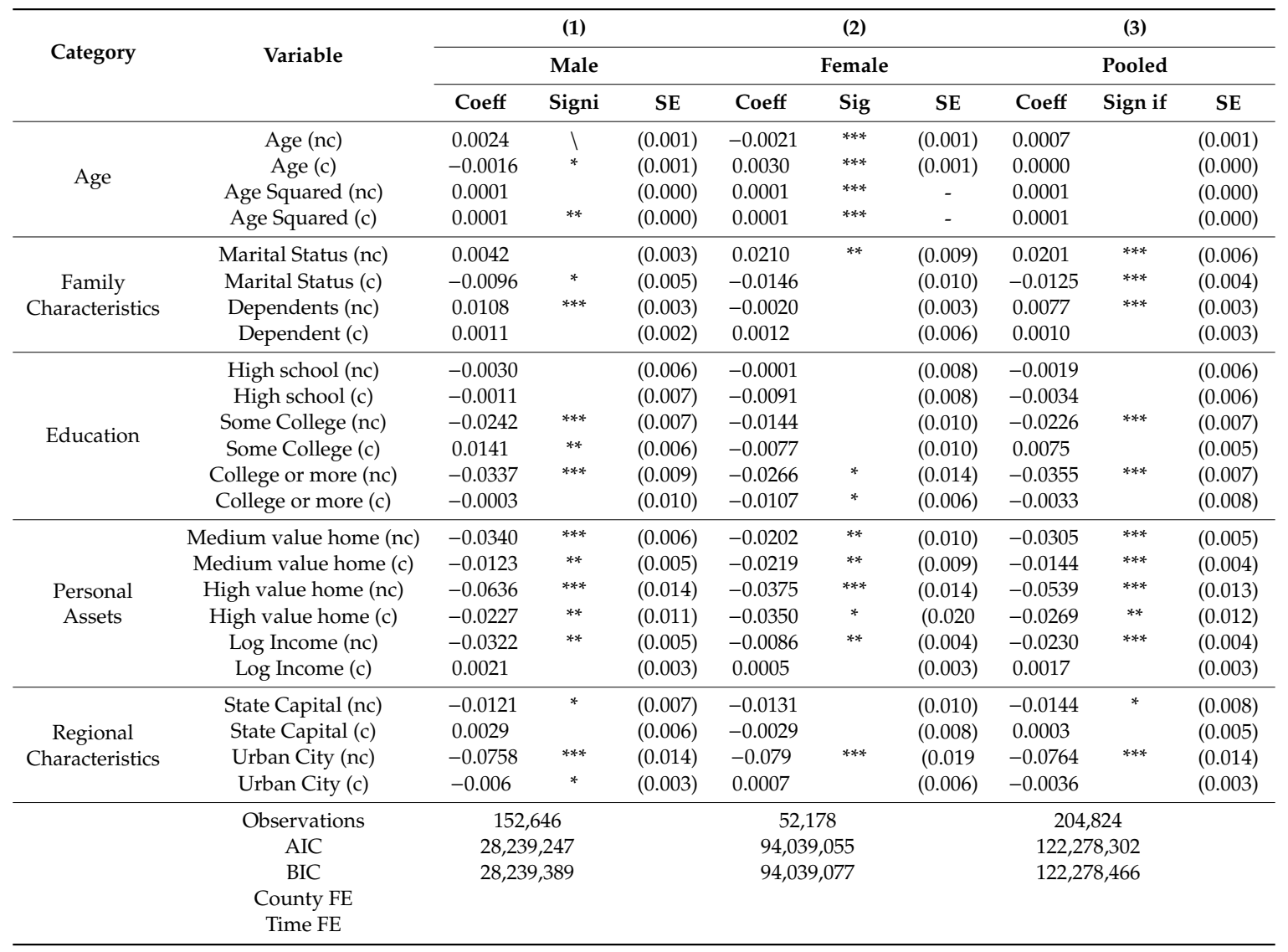

Notes: Standard errors in parentheses: ${ }^{*} p<0.10,{ }^{* *} p<0.05,{ }^{* * *} p<0.01$. (c) denote coefficient for the crisis period; (nc) non-crisis period.

As shown in Table 2, the effects of the Crisis on the SE sector were not as strong as was expected for the model estimated using the pooled data. However, there were some effects of the Crisis when the dataset was divided by gender.

\subsubsection{Age}

In the case of age, results were different for pooled, females', and males' datasets. For the pooled datasets, both age and age square were not statistically significant, implying that there was no age effect on the decision to become self-employed. However, there are differences in terms of the estimated coefficient between females and males. While the estimation of female participation in SE show a negative relationship between age and self-employment; that is, the older the female, the less likely to engage SE, while the males' estimate shows a positive relationship. This coefficient suggests a departure from the existing literature, suggesting that females engage in SE at an earlier age compared 
to males, who engage in them at a later age. During the Crisis, the effect of the age shifted from a negative sign before the Crisis to a positive sign. However, this shift was only statistically significant for females and males' subsets, but not for the pooled data. This result suggests that during the Crisis, males were more actively engaged in SE activity at earlier ages and females at later ages. The total impact of age over the SE probability is $0.07 \%$ for the pooled, $0.08 \%$ for males, and $0.09 \%$ for females.

\subsubsection{Family Characteristics}

Marital status shows a positive sign across all the subsets; however, coeffects are only significant for the pooled data and females. This result is in line with previous research that suggests that for a female, having a partner may encourage the household head to enter the SE sector in the non-Crisis period (Arenius and Kovalainen 2006). The Crisis showed a change of the sign of the coefficient from positive to negative is significant for the total population and males. The latter shows that males behave differently when a Crisis occurs in terms of entering the SE sector. The total effect of the marital status was $0.8 \%$ for the pooled, $-0.5 \%$ for males, and $0.6 \%$ for females.

The number of dependents also showed a positive sign and was statistically significant for the pooled and the males' coefficients. However, the female's subset had a negative yet not statistically significant relationship, and the latter result is unexpected since the literature suggests the opposite. The Crisis did not have a statistically significant impact on the importance of the number of dependents on the entry decision. The total effect of the number of dependents is $0.9 \%$ for the pooled, $1.2 \%$ for males, and $-0.1 \%$ for females. These results are similar to what Molina et al. (2016) found using a different dataset.

\subsubsection{Education}

The estimation results show that in the case of the household head, education has a statistically significant relationship for people with college and some college history, but not for the high school only category. The negative sign in these coefficients can be interpreted as an indication that a person with a higher level of education will be less likely to engage in SE activities. In terms of the gender, the negative impact of higher education on female SE is slightly lower than the general population, yet higher than the impact on males, suggesting that females are less likely to engage SE males, confirming the results found in the existing SE literature (Cuberes et al. 2019; Koellinger et al. 2013; Simon and Way 2016). However, none of the changes due to the Crisis were significant except for college, where there was a reduction of the impact of education on SE by $1.06 \%$ for females, and a reduction of $1.5 \%$ males with college degree.

\subsubsection{Personal Assets}

Both medium and high value houses, proxies for family collateral, had a statistically significant, negative impact for all the groups during the entire data collection period and during the Crisis. In the case of the females subset, the impact of house type is less than it was for the pooled or male subsets. However, the impact of the Crisis on this determinant was higher in females, indicating that it was less likely to move to the SE sector from a wage-paid position. The total effect of this coefficient over the probability of becoming self-employed was negative for all the cases.

The logarithm transformation of the total income of the household had a negative impact over self-employment, showing that the higher the level of income, the less likely it is that the head of the household would engage in SE activities with the female impact more than twice as much as the male. This result may indicate that males may take less risk than women and will engage in these activities regardless of household total income. The total effect of this coefficient is $-2.1 \%$ for the pooled, $-3.0 \%$ for males, and $-0.8 \%$ for females. 


\subsubsection{Regional Characteristics}

Both State Capital and Urban city factors had a negative impact on the SE decision. Results show that living in a state capital had a negative impact on all the groups, suggesting that there is no advantage of living in a state capital compared to a non-state capital. There was a change in the trend during the Crisis, shifting from negative to positive, but these results were not statistically significant. In the case of living in an urban settlement, results were similar to the state capital coefficient; that is, they had a negative impact over all the groups. This also suggests that self-employment was not affected by the difference in support and programs that are in urban areas compared to rural areas. The only significant impact of this determinant over the SE rate was during the Crisis, where the female coefficient increased the impact on $0.49 \%$.

Table 3 shows the fixed effects by CA during the Crisis and non-Crisis periods. The Crisis affected seven out the $15 \mathrm{CAs}$, changing from a positive (more SE activity) to a reduction in SE activity. Other CAs, such as Cantabria and Catalonia, presented an increase in SE activity during the Crisis period. Nevertheless, the vast majority of the CAs had a positive total effect over self-employment except for Canarias, Extremadura, and Madrid.

Table 3. CA Effects during the Crisis, non-Crisis, and total effect.

\begin{tabular}{cccccccc}
\hline \multirow{2}{*}{$\begin{array}{c}\text { Comunidad } \\
\text { Autonoma }\end{array}$} & \multicolumn{3}{c}{ Non-Crisis } & \multicolumn{3}{c}{ Crisis } & \multirow{2}{*}{ Total } \\
\cline { 2 - 6 } & Coeff & Sig & SD & Coeff & Sig & SD & \\
\hline Aragón & 0.0462 & $* * *$ & $(0.0037)$ & -0.0126 & $* * *$ & $(0.0021)$ & 0.0336 \\
Asturias & 0.0314 & $* * *$ & $(0.0020)$ & 0.0066 & $* * *$ & $(0.0009)$ & 0.0380 \\
Illes Balears & 0.0416 & $* * *$ & $(0.0026)$ & -0.0150 & $* * *$ & $(0.0011)$ & 0.0266 \\
Canarias & -0.0079 & $* * *$ & $(0.0009)$ & -0.0026 & $*$ & $(0.0013)$ & -0.0105 \\
Cantabria & 0.0054 & $*$ & $(0.0031)$ & 0.0212 & $* * *$ & $(0.0013)$ & 0.0266 \\
Castilla y León & 0.0401 & $* * *$ & $(0.0045)$ & 0.0049 & $* * *$ & $(0.0016)$ & 0.0450 \\
Castilla - La Mancha & 0.0226 & $* * *$ & $(0.0034)$ & -0.0030 & & $(0.0020)$ & 0.0196 \\
Cataluña & 0.0206 & $* * *$ & $(0.0022)$ & 0.0074 & $* * *$ & $(0.0007)$ & 0.0280 \\
Comunitat Valenciana & 0.0079 & $* * *$ & $(0.0015)$ & 0.0083 & $* * *$ & $(0.0005)$ & 0.0162 \\
Extremadura & -0.0096 & & $(0.0059)$ & -0.0051 & $* * *$ & $(0.0011)$ & -0.0147 \\
Galicia & 0.0422 & $* * *$ & $(0.0041)$ & 0.0088 & $* * *$ & $(0.0010)$ & 0.0510 \\
Madrid & -0.0031 & & $(0.0046)$ & -0.0055 & $* * *$ & $(0.0012)$ & -0.0086 \\
Murcia & 0.0198 & $* * *$ & $(0.0005)$ & -0.0082 & $* * *$ & $(0.0007)$ & 0.0116 \\
Navarra & 0.0054 & & $(0.0033)$ & -0.0040 & $* * *$ & $(0.0011)$ & 0.0014 \\
País Vasco & 0.0198 & $* * *$ & $(0.0028)$ & -0.0114 & $* * *$ & $(0.0008)$ & 0.0084 \\
La Rioja & 0.0447 & $* * *$ & $(0.0025)$ & 0.0032 & $* *$ & $(0.0015)$ & 0.0479 \\
\hline
\end{tabular}

Standard errors in parentheses: ${ }^{*} p<0.10,{ }^{* *} p<0.05,{ }^{* * *} p<0.01$.

\section{Discussion and Conclusions}

This paper examines how the determinants of SE entry decisions were affected by the 2008 financial Crisis and labor reform in Spain using data from Encuesta de Presupuestos Familiares (EPF). The decision to enter the self-employment sector was modeled as a function of a set of determinants categories such as age, family characteristics, education, personal assets, and regional characteristics. Using a logistic regression model, results shows that using the pooled data produces different results compared to separating the dataset by gender. Results show that determinants during the Crisis had a different coefficient compared to males. These results show the importance of having different layers of disaggregation to evaluate the effect of a Crisis over the self-employment sector. Also, results demonstrated that Comunidad Autonomas experienced different results in the non-Crisis and Crisis periods, showing some of them experienced resilience to the Crisis while others were more affected, suggesting an uneven impact of the Crisis across the Spanish territory.

The Crisis affected how workers decided whether they should enter the SE, yet not all the determinants experienced a statistically significant change due to the Crisis. Due to these results, it is 
not possible to assume that decision entry is stable over time and therefore hypothesis $\mathrm{H} 1$ cannot be rejected. Regarding the education category, results showed that although during the non-Crisis period, educated females tended to enter less frequently into self-employment, the Crisis did not have an effect on this trend. The only significant impact of the education level on SE was males with some college education, with an increase in the likelihood that this demographic would enter the SE sector. Therefore, hypothesis $\mathrm{H} 2$ can be rejected for females and partially for males. Finally, county fixed effects have shown that the CAs had different behaviors during Crisis and non-Crisis periods, with some of these CA experiencing a negative impact in Crisis while other CAs not experiencing any changes in SE activities. One of the interesting results was in Madrid. The expectation was that larger CAs would have higher resilience in times of Crisis, yet Madrid had a negative impact. This result contrasts with equivalent CAs such as Catalonia, which endured the Crisis with comparative success and did not experience a change in the SE trend.

From the policy standpoint of view, results can be used for adapting policies related to SE. Since the results show that education had a negative impact on SE, this can be interpreted as less educated people being moved from paid positions to SE positions; therefore, the nature of these SE positions is more about subsistence than innovation. This nature of the SE activity, along with the high unemployment rate, may indicate that SE did not act as a shock absorber in this Crisis, departing from the classic view, at least in developing countries, that SE is a shelter for workers who are laid off from paid positions. One potential recommendation would be that SE (and to some extent microenterprise) support programs should be modified during a financial Crisis period. Furthermore, not all of the regions had the same resilience to Crisis, creating the need to develop location-specific policies. Some regions were more friendly to SE than others, so the need for support should be less dire than in regions that had a negative shift in SE sector growth. Some of the results obtained in this research are in line with other research. For instance, the age determinant was not significant for the pooled dataset similar to what Arenius and Kovalainen (2006) determined. However, when the dataset was divided by gender, age became significant for the male subset. On the other hand, variables such as education had a different outcome compared to previous studies such as Simon and Way (2016), who found a positive relationship between college education not statistically significant. However, the latter research focuses on the gap income among self-employment earning rather than what drives the decision to become self-employed.

Even though this research is one of the first attempts to evaluate the effect of the Crisis over the SE sector, results need to be interpreted with some caution, due to caveats of the datasets. One of the first caveats is that this research cannot determine whether a person switched back and forth from SE to paid work or even became unemployed, precluding a better interpretation or analysis of the factors that motivated people to exit or entry the SE sector. Along with the lack of information on firm entry, there was limited information about the rest of the household members regarding education or current employment status; therefore, it is not possible to determine whether more people are self-employed or have a paid position.

In conclusion, this research sheds light on the existing gap of literature regarding the effect of a major financial crisis over the self-employment sector, namely the 2008 Spanish financial crisis. It is important to highlight that the self-employment sector in Spain had a downward trend even before the start of the Crisis, which can be interpreted that the crisis was already affecting this sector. As demonstrated in the exploratory and regression analysis, the female subset was more affected compared to the males, highlighting the importance of not only using pooled data but also some level of data disaggregation. These results stress that research should be done in the future on the factors that are different for females compared to males, using a mixed methods approach. The latter would allow knowing variables that are not normally included in a survey such as motivation, skill perception, and some other cultural issues such as the role of the female inside the household. Finally, this paper also contributes to the policy discussion, in the sense that in times of crisis, the policy should be adapted 
since some of the determinants of self-employment change, and therefore the programs and policies should adapt to those changes.

Funding: This work was partially funded by the CONICYT PFCHA/DOCTORADO BECAS CHILE/2014-72180000.

Acknowledgments: I thank Gregory Stanton for assistance with for comments that greatly improved the manuscript. Also, I thank to my Ph.D. advisor Geoffrey J. D. Hewings for his invaluable help and to my dissertation committee.

Conflicts of Interest: The author declares no conflict of interest.

\section{References}

Alba-Ramirez, Alfonso. 1994. Self-employment in the midst of unemployment: The case of Spain and the United States. Applied Economics 26: 189-204. [CrossRef]

Amit, Raphael, and Eitan Muller. 1995. "Push" and "Pull" Entrepreneurship. Journal of Small Business \& Entrepreneurship 12: 64-80. [CrossRef]

Arenius, Pia, and Anne Kovalainen. 2006. Similarities and Differences Across the Factors Associated with Women's Self-employment Preference in the Nordic Countries. International Small Business Journal 24: 31-59. [CrossRef]

Ariza Montes, J. Antonio, Mariano Carbonero Ruz, Belén Gutiérrez Villar, and M. Carmen López Martín. 2013. El trabajo autónomo: Una vía para el mantenimiento del empleo en una sociedad en transformación. CIRIEC-España, Revista de Economía Pública, Social y Cooperativa 78: 149-74.

Arrizabalo, Xabier, Patricia Pinto, and Lucía Vicent. 2019. Historical Significance of Labor's Increased Precariousness in Germany, the United Kingdom, and Spain. American Journal of Economics and Sociology 78: 255-90. [CrossRef]

Bargain, Olivier, and Laurine Martinoty. 2019. Crisis at home: Mancession-induced change in intrahousehold distribution. Journal of Population Economics 32: 277-308. [CrossRef]

Bartelheimer, Peter, Joan Miquel Verd, René Lehweß-Litzmann, Martí López-Andreu, and Tanja Schmidt. 2012. Unemployment, intervention and capabilities. A comparative study of Germany and Spain. Transfer: European Review of Labour and Research 18: 31-44. [CrossRef]

Bashir, Saima, Tesfa Gebremedhin, and Muhammad Arshad Chawdhry. 2014. Does Self-Employment Enhance Regional Economic Development. Journal of Developmental Entrepreneurship 19: 1-15. [CrossRef]

Bateman, Milford. 2000. Neo-Liberalism, SME Development and the Role of Business Support Centres in the Transition Economies of Central and Eastern Europe. Small Business Economics 14: 275-98. [CrossRef]

Berry, R. Albert, and Edgard Rodriguez. 2001. Dynamics of Small and Medium Enterprises in a Slow-Growth Economy: The Philippines in the 1990s. Washington, DC: World Bank Institute.

Blanchflower, David. 2004. Self-Employment: More May Not Be Better. Swedish Economic Policy Review 11: 15-74.

Blanchflower, David G., and Andrew J. Oswald. 1998. What makes an entrepreneur? Journal of labor Economics 16: 26-60. [CrossRef]

Blanchflower, David G., and Chris Shadforth. 2006. Entrepreneurship in the UK. Foundations and Trends ${ }^{\circledR}$ in Entrepreneurship 3: 257-364. [CrossRef]

Block, Jörn, and Philipp Sandner. 2009. Necessity and opportunity entrepreneurs and their duration in self-employment: Evidence from German micro data. Journal of Industry, Competition and Trade 9: 117-37. [CrossRef]

Bögenhold, Dieter, and Udo Staber. 1991. The Decline and Rise of Self-Employment. Work, Employment and Society 5: 223-39. [CrossRef]

Cetin, Dilek, Ana Fernandez-Zubieta, and Fulvio Mulatero. 2016. Formal and Informal Social Capital as Determinants of Male and Female Entrepreneurship in Europe. Cankiri Karatekin Universitesi Iktisadi ve Idari Bilimler Fakultesi Dergisi/Cankiri Karatekin University Journal of the Faculty of Economics and Administrative Sciences 6: 723-48.

Cuberes, David, Sadia Priyanka, and Marc Teignier. 2019. The determinants of entrepreneurship gender gaps: A cross-country analysis. Review of Development Economics 23: 72-101. [CrossRef]

Dawson, Christopher, and Andrew Henley. 2012. "Push" versus "pull" entrepreneurship: An ambiguous distinction? International Journal of Entrepreneurial Behavior \& Research 18: 697-719. 
De Meza, David, Christopher Dawson, Andrew Henley, and Gholamreza Reza Arabsheibani. 2019. Curb your enthusiasm: Optimistic entrepreneurs earn less. European Economic Review 111: 53-69. [CrossRef]

Estrin, Saul, and Tomasz Mickiewicz. 2011. Institutions and female entrepreneurship. Small Business Economics 37: 397-415. [CrossRef]

Evans, David S. 1987. The Relationship Between Firm Growth, Size, and Age: Estimates for 100 Manufacturing Industries. Journal of Industrial Economics 35: 567. [CrossRef]

Evans, David S., and Boyan Jovanovic. 1989. An Estimated Model of Entrepreneurial Choice under Liquidity Constraints. Journal of Political Economy 97: 808-827. [CrossRef]

Fairchild, Gregory B. 2009. Residential Segregation Influences on the Likelihood of Ethnic Self-Employment. Entrepreneurship Theory and Practice 33: 373-95. [CrossRef]

Fairlie, Robert W. 2004. Recent trends in ethnic and racial business ownership. Small Business Economics 23: 203-18. [CrossRef]

Gentry, William M., and R. Glenn Hubbard. 2000. Tax policy and entrepreneurial entry. American Economic Review 90: 283-87. [CrossRef]

Gentry, William M., and R. Glenn Hubbard. 2004. Entrepreneurship and Household Saving. Advances in Economic Analysis \& Policy 4. [CrossRef]

Gobillon, Laurent, and Thierry Magnac. 2015. Regional Policy Evaluation: Interactive Fixed Effects and Synthetic Controls. The Review of Economics and Statistics 98: 535-51. [CrossRef]

Goetz, Stephan J., and Anil Rupasingha. 2009. Determinants of growth in non-farm proprietor densities in the US, 1990-2000. Small Business Economics 32: 425-38. [CrossRef]

Hamilton, Barton H. 2000. Does Entrepreneurship Pay? An Empirical Analysis of the Returns to Self-Employment. Journal of Political Economy 108: 604-31. [CrossRef]

Holtz-Eakin, Douglas, David Joulfaian, and Harvey S. Rosen. 1994a. Entrepreneurial Decisions and Liquidity Constraints. The Rand Journal of Economics 25: 334-47. [CrossRef]

Holtz-Eakin, Douglas, David Joulfaian, and Harvey S. Rosen. 1994b. Sticking it Out: Entrepreneurial Survival and Liquidity Constraints. Journal of Political Economy 102: 53-75. [CrossRef]

Hughes, Karen D. 2003. Pushed or Pulled? Women's Entry into Self-Employment and Small Business Ownership. Gender, Work E Organization 10: 433-454. [CrossRef]

Hulme, David. 2000. Impact assessment methodologies for microfinance: Theory, experience and better practice. World Development 28: 79-98. [CrossRef]

Kirkwood, Jodyanne. 2009. Motivational factors in a push-pull theory of entrepreneurship. Gender in Management: An International Journal 24: 346-64. [CrossRef]

Koellinger, Philipp, Maria Minniti, and Christian Schade. 2013. Gender differences in entrepreneurial propensity. Oxford Bulletin of Economics and Statistics 75: 213-34. [CrossRef]

Lazear, Edward P. 2004. Balanced skills and entrepreneurship. American Economic Review 94: 208-11. [CrossRef]

Mandelman, Federico S., and Gabriel V. Montes-Rojas. 2009. Is Self-employment and Micro-entrepreneurship a Desired Outcome? World Development 37: 1914-25. [CrossRef]

Melián Navarro, Amparo, Joan Ramon Sanchis Palacio, and Francisco Soler Tormo. 2010. El Crédito Cooperativo como instrumento financiero para el fomento del emprendimiento en tiempos de crisis. Ciriec-España, revista de economía pública, social y cooperativa 68: 111-39.

Millán, José María, Emilio Congregado, and Concepción Román. 2012. Determinants of self-employment survival in Europe. Small Business Economics 38: 231-58. [CrossRef]

Molina, Jose Alberto, Velilla Jorge, and Ortega Raquel. 2016. The decision to become an entrepreneur in Spain: The role of household finances. International Journal of Entrepreneurship 20: 57-73.

Mortensen, Dale T. 1986. Job search and labor market analysis. Handbook of Labor Economics 2: 849-919.

Narjoko, Dionisius, and Hal Hill. 2007. Winners and Losers during a Deep Economic Crisis: Firm-level Evidence from Indonesian Manufacturing*. Asian Economic Journal 21: 343-68. [CrossRef]

Parker, Simon C. 1996. A Time Series Model of Self-employment under Uncertainty. Economica 63: 459-75. [CrossRef]

Prentice, Rebecca. 2017. Microenterprise development, industrial labour and the seductions of precarity. Critique of Anthropology 37: 201-22. [CrossRef]

Romero, Isidoro, and Juan A. Martínez-Román. 2012. Self-employment and innovation. Exploring the determinants of innovative behavior in small businesses. Research Policy 41: 178-89. [CrossRef] 
Roy, Ananya. 2010. Poverty Capital: Microfinance and the Making of Development. Abingdon: Routledge.

Rupasingha, Anil, and Sergio Contreras. 2014. Factors affecting spatial variation of microenterprises in the rural United States. American Journal of Entrepreneurship 7: 17.

Sanchez-Moral, Simón, Alfonso Arellano, and Roberto Diez-Pisonero. 2018. Interregional Mobility of Talent in Spain: The Role of Job Opportunities and Qualities of Places during the Recent Economic Crisis. Environment and Planning A 50: 789-808. [CrossRef]

Sandee, Henry Mickel, Roos Kities Andadari, and Sri Sulandjari. 2000. Small firm development during good times and bad: The Jepara furniture industry. In Indonesia in Transition. Social Aspects of Reformasi and Crisis. Singapore and London: Institute of Southeast Asian Studies/ZED Books, pp. 184-200.

Sevilla Jimenez, Martín, Teresa Torregrosa Marti, and María Nunez Romero. 2017. La informacion financiera y bancaria oficial y la ultima crisis economica (1999-2012). El caso del Banco de Espana. Estudios de Economia Aplicada 35: 583-610.

Simoes, Nadia, Nuno Crespo, and Sandrina B. Moreira. 2016. Individual determinants of self-employment entry: What do we really know? Journal of Economic Surveys 30: 783-806. [CrossRef]

Simon, Jessica K., and Megan McDonald Way. 2016. Why the Gap? Determinants of Self-Employment Earnings Differentials for Male and Female Millennials in the US. Journal of Family and Economic Issues 37: $297-312$. [CrossRef]

Steiner, Viktor, and Katharina Wrohlich. 2005. Work incentives and labor supply effects of the 'Mini-jobs reform'in Germany. Empirica 32: 91-116. [CrossRef]

Wennekers, Sander, and Roy Thurik. 1999. Linking entrepreneurship and economic growth. Small Business Economics 13: 27-56. [CrossRef]

(C) 2019 by the author. Licensee MDPI, Basel, Switzerland. This article is an open access article distributed under the terms and conditions of the Creative Commons Attribution (CC BY) license (http://creativecommons.org/licenses/by/4.0/). 